\title{
The "Production" of Accounting Information Between Regulatory and Free Market Approach: An (Eternally) Open Issue*
}

\author{
Marco Sorrentino, Francesco Cossu \\ Pegaso Telematic University, Naples, Italy \\ Margherita Smarra \\ University of Naples “Federico II”, Naples, Italy
}

\begin{abstract}
Accounting information has gained utmost importance over the years, and it now plays a vital role in our society. Indeed, the trends of a global economy, especially one relying on a capital market-based financial system, are greatly influenced by reliable accounting information. However, it is sometimes difficult to assess the "reliability" of such information, given the clear differences in the needs and goals of its different users. In this respect, the possible ways to guarantee the appropriateness of the accounting information provided to users doubtlessly deserve a careful investigation. The second half of the 1970s can be considered as the starting point of a debate, within the Anglo-Saxon accounting literature, concerning the most effective methods to provide users with accounting data effectively meeting their very specific needs. In this context, two antithetical schools of thought developed: (1) free market approach; and (2) regulatory approach. Although it is possible to state that accounting regulation has now become a concrete reality both inside and outside the Anglo-Saxon accounting context, after more than half a century, its efficacy is still an open issue.
\end{abstract}

Keywords: accounting information, free market, regulation, Anglo-Saxon accounting, agency theory, signalling theory, information asymmetry

\section{Introduction}

Accounting information has grown important over the years, and it now plays a vital role in the entire business community. Indeed, the trends of a global economy, especially one relying on a capital market-based financial system (Nobes, 1998), directly depend on the well-timed dissemination of quantitatively and qualitatively accurate accounting information by companies.

However, it is sometimes difficult to assess the "reliability" of such information, given the clear differences in the needs and goals of its different users. In this respect, the possible ways to guarantee the suitability of the accounting information provided to users doubtlessly deserve a careful investigation.

\footnotetext{
* Although this study is the joint result of the discussion among the authors, Section 1 has been developed by Margherita Smarra, Sections 2 and 3 have been developed by Marco Sorrentino, and Section 4 has been developed by Francesco Cossu.

Marco Sorrentino, Ph.D., senior lecturer in Business Administration, Department of Law and Economic Sciences, Pegaso Telematic University. Email: marco.sorrentino@unipegaso.it.

Francesco Cossu, senior lecturer in Business Law, Department of Law and Economic Sciences, Pegaso Telematic University. Margherita Smarra, Ph.D. student, Department of Economics, Management, and Institutions, University of Naples “Federico II”.
} 
The second half of the 1970s can be considered as the starting point of a debate, within the Anglo-Saxon accounting literature, concerning the most effective methods to provide users with accounting data effectively meeting their very specific needs. In this context, two antithetical schools of thought developed:

(1) Free market approach;

(2) Regulatory approach.

Accounting regulation has become well-established both inside and outside the environment in which Anglo-Saxon accounting developed, ${ }^{1}$ but after almost half a century, it is not possible to state that doctrine prefers the regulatory approach over the free market one for the "production" of accounting information (Gwilliam, Macve, \& Meeks, 2005). In this regard, it is worth mentioning that William H. Beaver ${ }^{2}$ uses the same sentence to conclude his analysis of this issue in three different editions of his most relevant work, Financial Reporting: An Accounting Revolution, stating that, “(...) As a result, the efficacy of regulation is an open issue” (Beaver, 1981, p. 201; 1989, p. 189; 1998, p. 171).

Considering this background and the great importance that the "production" of accounting information has always had in the Anglo-Saxon accounting context, ${ }^{3}$ this paper includes a critical analysis of the various theoretical arguments supporting either the free market approach (Section 2) or the regulatory approach (Section 3). The last part of this work (Section 4) contains the authors' concluding remarks.

\section{Theoretical Arguments for the Free Market Approach}

Underlying the free market approach is the idea that accounting information is an ordinary economic asset. Therefore, the demand for such information by different categories of users, combined with its supply by different companies in the form of financial statements, is supposed to trigger a natural exchange process resulting in its efficient dissemination in the market. In this context, free market is regarded as the most suitable means to define the ideal amount and kind of accounting information to be produced and subsequently supplied at the best price (Kam, 1990). Therefore, if some information deemed relevant is not made publicly available, the basic laws of supply and demand are supposed to ensure its efficient allocation among various users. ${ }^{4}$

In other words, the motivation to trade on the market the accounting information held by both "suppliers" (companies) and "consumers" (users) appears strong enough to make any regulation system unnecessary.

\footnotetext{
${ }^{1}$ This process is carried out in different ways even within the same Anglo-Saxon context, as pointed out by Nobes and Parker (1988, p. 63): "It is true that the ways in which accounting disclosure and measurement are set in the four countries (USA, UK, Canada e Australia) differ quite considerably".

${ }^{2}$ William $\mathrm{H}$. Beaver is one of the greatest representatives of both accounting doctrine and praxis in the world. At the time in which this paper is being written, Beaver is Professor Emeritus of Accounting at the Stanford University. From 1979 to 1981, he was the President of the American Accounting Association, and in 1996, he was appointed at the Accounting Hall of Fame.

3 The international doctrine includes several opinions about the Anglo-Saxon Accounting. Flower (1997) believed that International Accounting Standards Committee (IASC) (now the International Accounting Standards Board (IASB)) has been greatly influenced by the Anglo-Saxon Financial Accounting over time, thus implicitly accepting its existence, whereas Alexander and Archer (2000) tried to prove that the Anglo-Saxon Financial Accounting is nothing but a myth. However, Nobes (2003) wrote an article replying to Alexander and Archer's claims, stating that the existence of a common element underlying accounting in the Anglo-Saxon countries cannot be denied and that such element affects IASB's activities to some extent.

4 According to the dominant economic model, also known as the neoclassical economic theory, which originated in the last decades of the 19th century, perfectly competitive markets produce an efficient distribution of resources and reach an ideal balance point. The efficiency in the allocation of resources is usually measured by means of the Pareto optimality criterion: "According to the Pareto optimality criterion, resources are efficiently distributed in a given situation (X) when any reallocation of the same resources (situation Y) results in: a) at least one party acquiring an amount of resources which is both higher and better than the one he had in situation $\mathrm{X}$; b) at least one party acquiring an amount of resources which is lower and worse than the one he had in situation X. In other words, it is not possible to reallocate resources to improve the condition of a party without worsening the condition of another one" (Venturello, 1997, p. 23).
} 
Indeed, users need relevant accounting data to take their economic decisions, while managers are motivated to provide the market with accurate and adequate information in order to attract and keep sufficient resources in their companies. ${ }^{5}$

In this context, an attempt can be made to logically arrange the various theories supporting the free market approach which appeared over time:

(1) Agency theory;

(2) Signalling theory;

(3) Private trading opportunities (Wolk, Dodd, \& Rozicky, 2012).

According to the agency theory, each company is the intersection point of the contractual relationships among the different parties involved in the company's activities ("nexus of contracts"). Moreover, the same theory also suggests that every person involved always acts in a way that protects his/her interests, which in some cases may be contrary to the interests of the company itself. However, the interpretation of the agency theory from an economic perspective laid the foundations of the legal concept of agency, in which the agent is a person who represents the interests of another party known as the principal.

When the agency theory is applied to accounting, the interests of owners (principals) and administrators (agents) are usual kept separate, as a natural consequence of the increasing development of limited liability companies (Jensen \& Meckling, 1976). ${ }^{6}$

The owners of a company hire a manager to administer the company's resources. However, while the owners aim at maximizing the total return on the investments made, the manager pursues different and more wide-ranging economic and psychological goals (including, for example, the increase of his remuneration or the improvement of his personal reputation). In order to cope with this potential conflict of interest and to minimize the difficulty that shareholders face in checking their managers' behavior, agreements are usually signed by agents and principals, in an attempt to make their respective goals as matching as possible. ${ }^{7}$ However, since monitoring the managers' activities is an expensive process, the costs incurred by the owners of a company while carrying out this task always affect managers and are likely to cause a decrease in their remuneration.

As a logical result of this, supporters of this theory argue that managers are motivated to provide adequate and reliable information to owners on a voluntary basis, in order to reduce the "monitoring costs" in the relationship between agents and principals (Watts \& Zimmerman, 1978).

Indeed, the evaluation and the remuneration of managers depend, at least partly, on the adequacy of the actual information they provide. Therefore, the more shareholders consider such information reliable, the better the reputation and remuneration of the managers become, as a result of a reduction in the "monitoring costs" (Holthausen \& Leftwich, 1983).

The theory outlined by Jensen and Meckling (1976), according to which the submission of revised reports pushes managers to minimize the aforementioned costs, has also been widely used by authors to support the voluntary request for the audit of accounting documents by an independent party, even without specific rules (Watts, 1977; Watts \& Zimmerman, 1983; Morris, 1984; Francis \& Wilson, 1988; Beaver, 1998).

\footnotetext{
${ }^{5}$ Foster (1986) provided empirical evidence for the voluntary supply of accounting data, not based on any existing regulation.

${ }^{6}$ Several studies written after Jensen and Meckling's work deal with the application of the agency theory to the relationship between managers and shareholders. For our analysis, the following studies are especially important: Leftwich (1983); Fama and Jensen (1983a; 1983b); and Harris and Raviv (1979).

${ }^{7}$ Under such agreements, the remuneration of managers may vary depending on the economic results of the company, or the usual stock option method may be employed.
} 
When the manager-shareholder relationship is placed in a broader context comprising the whole capital market, the voluntary supply of "revised" information becomes an indicator of the quality of the managers' work, from which actual and potential investors operating on the market are likely to take advantage (Taylor \& Turley, 1986).

Companies compete with one another to attract and retain the "limited" economic resources available. Such companies have access to an amount of information about their own activities that is much greater than the data available to third parties, and therefore have to disclose such information in an adequate and reliable way, in order to keep operating on the markets successfully (Ross, 1979).

The information asymmetry affecting investors and their uncertainty state which, in a competitive capital market, are associated with the incentive to disseminate even bad news (an indirect consequence of the "Market for Lemons" theory outlined by Akerlof (1970)), underlie the so-called signaling theory (Deegan \& Samkin, 2004; Scott, 2003; Spence, 1974).

Applying this theory to accounting matters means that a company can reduce the uncertainty state of investors by voluntarily making reliable accounting information available to them (sending adequate signals to the market). This, in turn, results in a decrease in the costs incurred to acquire the risk capital and increases the value of the company. ${ }^{8}$

According to another model, which provides a corollary to the argument for the preeminence of the free market approach, managers are better than any regulatory agency in defining the type and amount of the accounting information necessary to make external investors as confident as possible, thus reducing the costs incurred by companies to gather the resources they need.

Finally, at the end of this logical examination, it is worth mentioning the argument for the private trading of accounting information. Underlying this argument is the belief that everyone who wants to obtain data about a specific company should be able to get them, applying the basic supply and demand laws.

In this analysis, the agency theory has been used to illustrate the factors that push managers to voluntarily disclose accounting information to shareholders, while the signalling theory, which is itself a natural consequence of competitive capital markets, includes strong arguments for a wider voluntary disclosure of information to all the investors on the market. However, if there are reasons to believe that some relevant information has not been voluntarily disclosed, they can be privately traded.

\section{Theoretical Arguments for the Regulatory Approach}

The various arguments for the regulatory approach presented in the Anglo-Saxon literature are parts of two main trends, according to which accounting regulation is:

(1) A necessary device to fix potential market failures;

(2) An instrument to make social choices and guarantee the level playing field. ${ }^{9}$

Despite the fact that the two approaches appear to be antithetical, they are actually interdependent, since they both envisage a regulatory activity based on public interest evaluations in terms of efficiency and equality, respectively (Cooper \& Keim, 1983).

\footnotetext{
${ }^{8}$ Several theoretical and empirical studies support this view, such as Dye (1990), Holthausen and Verrecchia (1988), Leftwich, Watts, and Zimmerman (1981), Wong (1988), and Skinner (1994).

9 The need to prevent frauds and abuses is also used to justify the government intervention in the accounting field, since such unlawful acts would eventually undermine the community's confidence in the capital market. However, this argument is often, and perhaps more accurately, interpreted as a potential consequence of market failures rather than as an independent reason, as Beaver (1998, pp. 161-162) pointed out.
} 
Indeed, an efficient allocation of resources is strongly related to an initial presumption of equality, which aims at defining the most adequate ways to disseminate information among users.

Unlike advocates of the free market approach, supporters of the first mentioned trend (the one dealing with market failures) believe that the specific features of accounting information make it impossible to treat such data as ordinary economic assets. Therefore, in some cases, the necessary conditions for an efficient allocation of resources may not be detected, causing a failure of the free market system in ensuring an optimal and balanced supply of this kind of information.

The efficient allocation of resources within a market requires, among other things, that all the involved parties be subject to the same prices. As a result, when there is only one producer (namely, monopoly), the actual demand for resources by consumers cannot be satisfied, because monopolists are free to decide the amount of products to distribute, creating a system of different prices.

The application of these principles to accounting would create a market failure, because the monopolistic methods adopted by companies in the production of accounting information would result in a reduced supply of accounting data, at a suboptimal price. In this respect, the introduction of a regulation system is likely to prevent users from competing with one another within an "inefficient" market, reducing their possible social costs.

Goods and services must be produced and sold according to the traditional law of supply and demand, for the market to work in an efficient way. When this does not happen, an externality occurs, i.e., a situation in which the productive activities carried out by a party affect the utility of other parties. ${ }^{10}$

A typical externality occurs for goods, the use of which by one individual does not reduce their availability to others. These goods are usually termed as public goods. ${ }^{11}$ In such a case, an externality, and thus a market failure, occurs, because the producer of a public good is unable to charge consumers for the production costs, and therefore is not motivated to produce the good. At the same time, the actual demand for a public good can never be reliably assessed, due to the presence of some individuals (free riders) who are not motivated to explicitly request a good, because they know that they can use it freely and unlimitedly.

Due to its features, accounting information (and information in general) cannot be placed among public goods (Godenes \& Dopuch, 1974; May \& Sundem, 1976; Solomons, 1983; Healy \& Palepu, 2001). Therefore, supporters of this theory argue that companies should be required to disclose at least a small amount of such information, in order to prevent its "underproduction" and increase the whole community's trust in the capital market (Cooper \& Keim, 1983).

Besides taking into account the various market failure scenarios, supporters of accounting regulation also argue that the free market approach cannot achieve the social goal of ensuring an equal dissemination of similar accounting information among users, even when it attains an optimal balance point.

Doctrine also refers to the need to ensure a "level playing field", a situation in which all the parties in a market have the same opportunities and can access the same information (Deegan \& Samkin, 2004), as an additional justification for accounting regulation. When this does not happen, an information asymmetry occurs.

The analysis of this notion from a purely accounting perspective helps define two particular cases in which the unequal supply of information results in a non-level playing field:

\footnotetext{
${ }^{10}$ When the utility of the other parties increases, the externality is positive, whereas when their utility decreases, the externality is negative.

${ }_{11}$ Bowers (1974) provided a comprehensive discussion of public goods.
} 
(1) Information asymmetry among different investors;

(2) Information asymmetry between investors and managers.

In the first case, there is a contrast between a small number of more-informed investors and a much larger group of less-informed investors, within the same market. In such a scenario, the former are likely to engage in an intense trading activity at the expense of the latter, in order to take advantage of the information they have access to.

Therefore, according to this theory, not only does the mandatory dissemination of a minimum amount of information achieve a social goal, but it also helps improve efficiency by reducing the "unproductive costs" incurred during the search for information (G. Meeks \& G. Meeks, 2002) by the less-informed parties (Hirshleifer, 1971).

As for the information asymmetry between investors and managers, it usually produces two well-known phenomena, namely, adverse selection and moral hazard.

In both cases, it is assumed that managers or other individuals within a company (the so-called insiders) have access to a larger amount of information than third parties in the market. By using this information, insiders have the opportunity to increase their profits, a situation which is against the interests of investors. However, third parties aware of such an unequal distribution of information may decide, in extreme circumstances, to leave the market simultaneously, as a defense mechanism (Lev, 1988).

When discussing the information asymmetry in the manager-shareholder relationship, an additional phenomenon, known as moral hazard, should be mentioned, namely, a situation in which shareholders are unable to check the behavior of managers, due to the separation of control and ownership. Indeed, managers have access to a larger amount of information about the actual performance of the company and are likely to take advantage of this to pursue their personal interests at the expense of the whole company (Scott, 2003).

In the light of adverse selection and moral hazard, those who advocate an external intervention in the accounting activity reject the theories underlying the free market approach, according to which a well-functioning market would induce managers to voluntarily disclose reliable and relevant information and make it available to both single shareholders and general investors.

We reach similar conclusions when comparing accounting information regarded as a public good or the monopolistic practices (which, according to supporters of the regulatory approach, are carried out by companies) with a hypothetical, effective private trading of accounting information, which underlies the free market system.

It therefore follows that the different theoretical arguments supporting each of the two approaches (free market or regulatory) can be regarded as antithetical interpretations of specular circumstances, carried out by means of mostly deductive analyses.

\section{Summary and Conclusions}

Following our analysis, it is safe to assume that a regulation of the accounting activity as extensive as the one currently applied in our context cannot be deemed necessary based on the two aforementioned theoretical approaches alone. $^{12}$

\footnotetext{
${ }^{12}$ It is worth mentioning that even the scant empirical research dealing with this topic (the so-called "capital market research") does not provide an adequate support. These studies only state that the information received by investors as a result of companies applying the accounting standards is important in "absolute" terms, but do not take into account any non-regulated scenario, as Healy and Palepu (2001) clearly pointed out.
} 
It seems safe to assume that the drawbacks of the free market may be overcome and a more efficient and equal allocation of the accounting information may be achieved, but at the same time, the direct and indirect costs incurred as a result of the implementation and the operation of an accounting regulation system must also be taken into account.

The extent, and especially the convenience, of any accounting regulation system should be carefully determined by means of an empirical cost-benefit analysis, as authors generally point out (Demski \& Feltham, 1976; Cooper \& Keim, 1983; Scott, 2003; Wolk et al., 2012). In this regard, Watts and Zimmerman (1986, p. 178) accurately stated that, “(...) There is no clear justification for corporate disclosure regulation. It is an empirical question of costs and benefits".

The economic consequences of the different accounting policies (Zeff, 1978) also support the belief that accounting is not only a matter of economic efficiency and Pareto optimality, but also has social connotations. According to the so-called capture theory, accounting regulation originates when specific interest groups try to increase the profits of their members by means of either political (the political ruling-elite theory of regulation) or economic power (the economic theory of regulation) (Belkaoui, 2004; Deegan \& Samkin, 2004; Mathews \& Perera, 1996; Phillips \& Zecher, 1981).

In this respect, the analysis of the historical evolution of accounting regulation in the Anglo-Saxon context shows that periods marked by a lower degree of regulation (laissez-faire) are cyclically interrupted by the introduction of extensive regulation measures, as a direct consequence of "scandals" or financial collapses. ${ }^{13}$ And it is worth mentioning that governments have conveniently used such measures in order to carry out their programs not only from an economic perspective, but also (or, perhaps, especially) from a political one.

\section{References}

Akerlof, G. A. (1970). The market for "lemons": Quality uncertainty and the market mechanism. The Quarterly Journal of Economics, 84(3), 488-500.

Alexander, D., \& Archer, S. (2000). On the myth of “Anglo-Saxon” financial accounting: A response to Nobes. The International Journal of Accounting, 35(4), 539-557.

Beaver, W. (1981). Financial reporting: An accounting revolution (1st ed.). Englewood Cliffs, NJ: Prentice Hall.

Beaver, W. (1989). Financial reporting: An accounting revolution (2nd ed.). Englewood Cliffs, NJ: Prentice Hall.

Beaver, W. (1998). Financial reporting: An accounting revolution (3rd ed.). Upper Saddle River, NJ: Prentice Hall.

Belkaoui, A. R. (2004). Accounting theory (5th ed.). London: Thomson.

Bowers, P. F. (1974). Private choice and public welfare: The economics of public goods. New York, NY: The Dryden Press.

Cooper, K., \& Keim, G. D. (1983). The economic rationale for the nature and extent of corporate financial disclosure regulation: A critical assessment. Journal of Accounting and Public Policy, 2(3), 189-205.

Deegan, C., \& Samkin, G. (2004). New Zealand financial accounting. Auckland, New Zealand: McGraw-Hill.

Demski, J., \& Feltham, G. (1976). Cost determination: A conceptual approach. Ames, IA: Iowa State University Press.

Dye, R. A. (1990). Mandatory versus voluntary disclosures: The cases of financial and real externalities. The Accounting Review, 65(1), 1-24.

Fama, E., \& Jensen, M. C. (1983a). Separation of ownership and control. Journal of Law and Economics, 26(2), 301-326.

Fama, E., \& Jensen, M. C. (1983b). Agency problems and residual claims. Journal of Law and Economics, 26(2), 327-350.

\footnotetext{
${ }^{13}$ Two examples of this are the Sarbanes-Oxley Act, issued in the United States after the Enron scandal, and the Joint Stock Companies Act (the first law of the British Government dealing with the regulation of the accounting information), which followed the collapse of the first joint-stock partnerships founded after the industrial revolution of the 18th century. It was subsequently amended by the Joint Stock Companies Act of 1856 and was followed by a long period marked by laissez-faire, but as more scandals occurred at the end of the 19th century, the Companies Act was issued in 1900, making the disclosure of information mandatory.
} 
Flower, J. (1997). The future shape of harmonization: The EU versus the IASC versus the SEC. European Accounting Review, 6(2), 281-303.

Foster, G. (1986). Financial statement analysis (2nd ed.). Englewood Cliffs, NJ: Prentice Hall.

Francis, J. R., \& Wilson, E. R. (1988). Auditor changes: A joint test of theories relating to agency costs and auditor differentiation. The Accounting Review, 63(4), 663-682.

Godenes, N. J., \& Dopuch, N. (1974). Capital market equilibrium, information production, and selecting accounting techniques: Theoretical framework and review of empirical work. Journal of Accounting Research, 12(3), 48-129.

Gwilliam, D., Macve, R., \& Meeks, G. (2005). The costs and benefits of increased accounting regulation: A case study of Lloyd's of London. Accounting and Business Research, 35(2), 129-146.

Harris, M., \& Raviv, A. (1979). Optimal incentive contracts with imperfect information. Journal of Economic Theory, 20(2), 231-259.

Healy, P. M., \& Palepu, K. G. (2001). Information asymmetry, corporate disclosure, and capital markets: A review of the empirical disclosure literature. Journal of Accounting and Economics, 31(1-3), 405-440.

Hirshleifer, J. (1971). The private and social value of information and the reward to inventive activity. American Economic Review, 61(4), 561-574.

Holthausen, R. W., \& Leftwich, R. W. (1983). The economic consequences of accounting choice: Implications of costly contracting and monitoring. Journal of Accounting and Economics, 5(2), 77-117.

Holthausen, R. W., \& Verrecchia, R. E. (1998). The effect of sequential information releases on the variance of price changes in an intertemporal multi-asset market. Journal of Accounting Research, 26(1), 82-106.

Jensen, M. C., \& Meckling, W. H. (1976). Theory of the firm: Managerial behavior, agency costs, and ownership structure. Journal of Financial Economics, 3(4), 305-360.

Kam, V. (1990). Accounting theory. New York, NY: John Wiley \& Sons.

Leftwich, R. W. (1983). Accounting information in private markets: Evidence from private lending agreements. The Accounting Review, 58(1), 23-42.

Leftwich, R. W., Watts, R. L., \& Zimmerman, J. L. (1981). Voluntary corporate disclosure: The case of interim reporting. Journal of Accounting Research, 19, 50-77.

Lev, B. (1988). Toward a theory of equitable and efficient accounting policy. The Accounting Review, 63(1), 1-22.

Mathews, M. R., \& Perera, M. H. B. (1996). Accounting theory and development. Melbourne: Thomas Nelson Australia.

May, R., \& Sundem, G. L. (1976). Research for accounting policy: An overview. The Accounting Review, 51(4), 747-763.

Meeks, G., \& Meeks, G. (2002). Towards a cost-benefit analysis of accounting regulation. ICAEW.

Morris, R. D. (1984). Corporate disclosure in a substantially unregulated environment. Abacus, 20(1), 52-86.

Nobes, C. (1998). Towards a general model of the reasons for international differences in financial reporting. Abacus, 34(2), 162-187.

Nobes, C. (2003). On the myth of “Anglo-Saxon” financial accounting: A comment. The International Journal of Accounting, 38(1), 95-104.

Nobes, C., \& Parker, R. (1988). Issues in multinational accounting. Oxford: Philip Allan/St Martin’s Press.

Phillips, S., \& Zecher, R. J. (1981). The SEC and the public interest. Cambridge, MA: The MIT Press.

Ross, S. A. (1979). Disclosure regulation in financial markets: Implications of modern financial theory and signaling theory. In F. Edwards (Ed.), Key issues in financial regulation (pp. 177-202). New York, NY: McGraw-Hill.

Scott, W. R. (2003). Financial accounting theory. Toronto, Ontario: Prentice Hall.

Skinner, D. J. (1994). Why firms voluntarily disclose bad news? Journal of Accounting Research, 32(1), 38-60.

Solomons, D. (1983). The political implications of accounting and accounting standard setting. Accounting and Business Research, 13(50), 107-118.

Spence, A. (1974). Market signalling: Informational transfer in hiring and related screening processes. Cambridge, MA: Harvard University Press.

Taylor, P., \& Turley, S. (1986). The regulation of accounting. Oxford: Basil Blackwell.

Venturello, M. (1997). La Milza del Sig. Moore: Una prospettiva di Comparative and Economic Analysis of Law. Retrieved from http://www.jus.unitn.it/cardozo/Review/Property/Venturello-1997/milzas.htm

Watts, R. L. (1977). Corporate financial statements: A product of the market and political process. Australian Journal of Management, 2(1), 53-75. 
Watts, R. L., \& Zimmerman, J. L. (1978). Towards a positive theory of the determination of accounting standards. The Accounting Review, 53(1), 112-134.

Watts, R. L., \& Zimmerman, J. L. (1983). Agency problems, auditing, and the theory of the firm: Some evidence. Journal of Law and Economics, 26(3), 613-633.

Watts, R. L., \& Zimmerman, J. L. (1986). Positive accounting theory. Englewood Cliffs, NJ: Prentice Hall.

Wolk, H. I., Dodd, J. L., \& Rozicky, J. J. (2012). Accounting theory: Conceptual issues in a political and economic environment (8th ed.). Sage Publications.

Wong, J. (1988). Economic incentives for the voluntary disclosure of current cost financial statements. Journal of Accounting and Economics, 10(2), 151-167.

Zeff, S. (1978). The rise of “economic consequences”. Journal of Accountancy, 146(6), 56-63. 